Vol. 10 (2): 409-420 (2020)

\title{
FORESTS FORMATION ON POST-AGRARIAN TERRITORIES OF TUNKA DEPRESSION (South-Western Pre-Baikal, Russia)
}

\author{
Alexander Sizykh ${ }^{1 *}$, Victor Voronin ${ }^{1}$, Alexander Gritsenyuk ${ }^{2}$, Alexey Shekhovtsov ${ }^{3}$ \\ $1^{*}$ Siberian Institute of Plants Physiology and Biochemistry of RAS SB, 664033 Irkutsk, 132 Lermontova str., Russia; \\ ${ }^{2}$ V.R. Filippov Buryat State Academy of Agriculture, 670024 Ulan-Ude, 1 Pushkina str., Russia; \\ ${ }^{3} V . B$. Sochava Institute of Geography of RAS SB, Irkutsk 664033, 1 Ulan-Batorskaya str., Russia; \\ *Corresponding Author Alexander Sizykh e-mail: alexander.sizykh@gmail.com;
}

Received April 2020; Accepted May 2020; Published June 2020;

DOI: https://doi.org/10.31407/ijees10.222

\begin{abstract}
The peculiarities of structural-dynamic organization of phytocoenoses at the contact of forests and extrazonal steppe are found out. The studied area is characterized by light-coniferous forests and by extrazonal (depression type) steppe cenoses forming on the valley bottom and along its boards and slopes trails of different expositions. The phytocoenoses of such habitats were used for a long period for pasturage and their considerable part was ploughed up for agriculture in the first half of last century. Nowadays they are mainly not used - these are fallows. It is noticed that during last 25-40 years, forests form steadily on the fallows and territories used before for pasturage. This is mainly due to changing environmental conditions as well as with the character of anthropogenic impact such as pasturage, ploughing up, cutting and fires during last decades. Formation of light-coniferous forests of zonal type is characteristic for the whole Tunka valley.
\end{abstract}

Keywords: forests formation, fallows, pastures, South-Western Pre-Baikal 